\title{
Factors Influencing the Implementation of Differentiated Instruction in English Language Instruction in Rural and Urban Secondary Schools of Johor Bahru
}

\author{
Marsha Lavania, Faizah Mohamad Nor \\ Faculty of Social Sciences and Humanities, Universiti Teknologi Malaysia, Iskandar Puteri, Malaysia \\ Email: marshalavania@gmail.com
}

How to cite this paper: Lavania, M., \& Nor, F. M. (2021). Factors Influencing the Implementation of Differentiated Instruction in English Language Instruction in Rural and Urban Secondary Schools of Johor Bahru. Creative Education, 12, 1235-1246. https://doi.org/10.4236/ce.2021.126093

Received: May 7, 2021

Accepted: June 8, 2021

Published: June 11, 2021

Copyright () 2021 by author(s) and Scientific Research Publishing Inc. This work is licensed under the Creative Commons Attribution International License (CC BY 4.0).

http://creativecommons.org/licenses/by/4.0/

\section{(c) (i) Open Access}

\begin{abstract}
When the effectiveness of an instruction is based on the outcomes of the students at the end of the lessons, the heterogeneity of the classroom could not be ignored. Considering the fact that Malaysian classrooms consist of mixed-ability students, the Cambridge Baseline Study (CBS), which was conducted in 2013, prior to the education reformation, emphasised the use of Differentiated Instruction (DI). Since DI is relatively new to the Malaysian education system, little is known of the phenomenon of its implementation from various aspects, namely, its effectiveness, teachers' readiness, challenges faced, factors significant to its implementation, students' and teachers' perceptions, its aptness to Malaysian classrooms and needs of relevant stakeholders. In relation to this, the current study aims to investigate the factors influencing DI implementation in English language instruction. In addition, it also seeks to reveal if there are differences in the influencing factors between rural and urban schools. English language teachers from ten schools in Johor Bahru were selected for semi-structured interviews which revealed that teachers consider aspects related to Curriculum, Instruction, Knowledge of DI, School, Students, Time and Workload in the implementation of DI, and that there was no significant difference between the factors considered in rural and urban schools. Implications and future studies are discussed.
\end{abstract}

\section{Keywords}

Differentiated Instruction, Rural Schools, English Language Instruction

\section{Introduction}

With the paradigm shift from teacher-centred to student-centred instruction, 
attention has been fixated on the needs and abilities of the students in ensuring effective instruction. Teachers employ their own methods in professionalising teaching and learning according to the changing demands of student-centred education policies based on the experience that they go through during their career (Valiandes, 2015). When the effectiveness of an instruction is based on the outcomes of the students at the end of the lessons, the heterogeneity of the classroom could not be ignored. Considering the fact that Malaysian classrooms consist of mixed-ability students, the Cambridge Baseline Study (CBS), which was conducted in 2013, prior to the education reformation, emphasised the use of Differentiated Instruction (DI). DI prioritises students' needs with the purpose of establishing meaningful learning and therefore negates the "one-size-fits-all" approach (Lavania \& Nor, 2020). DI has been proven by extensive literature to be effective in catering to students' needs and strengthening their progress in mastering the target language (Schleicher, 2016; Jacobse et al., 2019; Van Casteren et al., 2017). In line with the suggestion provided in the CBS, the Malaysian education reformation which was initiated in 2018 simultaneously across the country urged English language teachers to employ DI in their teaching (Don et al., 2015). The commencement on DI implementation was put into action progressively, beginning from Form 1 and Form 2, through the revision of textbooks, Scheme of Work (SOW) and the guidance through trainings and sample teaching materials and lesson plans. With drastic changes to all essential documents related to teaching, teachers have no choice but to familiarise themselves with the new implementation and start implementing it in their English lessons. As mentioned above, theoretically, DI is efficient in improving instruction for mixed-ability classes. Its practicality is tested when teachers implement it in Malaysian classrooms. Since DI is relatively new to the Malaysian education system, little is known of the phenomenon of its implementation from various aspects, namely, its effectiveness, teachers' readiness, challenges faced, factors significant to its implementation, students' and teachers' perceptions, its aptness to Malaysian classrooms and needs of relevant stakeholders. In relation to this, the current study aims to investigate the factors influencing DI implementation in English language instruction. In addition, it also seeks to reveal if there are differences in the influencing factors between rural and urban schools. The abovementioned aims were realised by centring on government-funded secondary schools in Johor Bahru, Malaysia. Therefore, two research questions that have been formulated are:

1) What are the factors that influence the implementation of differentiated instruction in English language instruction in secondary schools of Johor Bahru?

2) Are the influencing factors different between rural and urban secondary schools of Johor Bahru?

\section{Literature Review}

Since Malaysia accomplished its independence, educators have encountered and gone along with different training changes beginning from the "nationalistic 
change" when, in 1961, the medium of instruction in schools was changed from English to the national language, Bahasa Malaysia. Following this change; as there were less opportunities to communicate in the language; naturally, there was an abatement in English capability (Mohamed et al., 2008), for which, as per Jalleh (2013) and Aruna (2014), English language educators were blamed. Another language related change occurred forty years later, in 2003 where the medium of instruction for two subjects; in particular, Mathematics and Science was changed to English. This approach was named English for Teaching Mathematics and Science (ETeMS). The reason for this change was to shape students to be capable in Mathematics and Science being in the language that is globally utilized. For students to be skillful in the previously mentioned subjects, they should first be capable in English. This acknowledgment put incredible accentuation on English language proficiency. However, the reformation, which was carried out in stages, received negative feedback from numerous parties. Apprehension relating to students performing gravely in Mathematics and Science because of poor English proficiency (Selamat et al., 2011; Norfaizah \& Marzilah, 2010), educators confronting difficulties in instructing because of the absence good proficiency or not being prepared to teach in English (Selamat et al., 2011; Selvaraj, 2010), rural schools facing disadvantages in facilities and exposure and significantly poorer outcomes in both subjects for the public exams (Rashid, 2016) prompted the abolishment of the approach by then education minister, Tan Sri Muhyiddin in 2012. The medium of instruction for the two subjects returned to Bahasa Malaysia. Albeit the inversion was done dependent on solid legitimizations from the service, there were numerous parties who supported the ETeMS; in particular the upper- and working-class parents and students (Rashid, 2016) with the explanations that learning Mathematics and Science in English will empower students to stay aware of the pace of international developments (Nor et al., 2011). To supplant the ETeMS, the ministry concocted another strategy in 2012 called Memartabatkan Bahasa Malaysia Memperkukuh Bahasa Inggeris (MBMMBI), and it was the beginning stage which illustrated and recognized the role of English and Bahasa Malaysia in the instruction framework, trailed by the Malaysian Education Blueprint (MEB) in year 2013, which diagrammed the arrangement for the reformation till year 2025. Aside from that, the report of the Cambridge Baseline Study (CBS) which was produced in year 2013 too, gave a rich outline on the situation with the Malaysian education framework at that point of time.

An idea that Tomlinson desires to be remembered is "in a differentiated classroom, the teacher proactively plans and carries out varied approaches to content, process, and product in anticipation of and response to student differences in readiness, interest, and learning needs" (2010). The possibility of differentiation itself includes breaking down students' disparities, considering them, and upgrading learning circumstances (Tahiri et al., 2017). This shows that educators assume an essential part in the execution of DI in the classroom. Educators assume the part of facilitators while students assume the responsibili- 
ties for the extension of their insight through exercises in or out of the classroom (Robinson, 2013). The thought of DI itself, as indicated by Blackburn \& Pennell (2018) lies on an allowance of expectations. Firstly, the conviction that students differ in numerous components, for example, "abilities, interests, styles, gifts, qualities and shortcomings". Besides, every student ought to get fair opportunities for viable learning in a "conscious way". Besides that, the instructions should suit "students' readiness levels, interest and learning profiles" (Tomlinson \& Imbeau, 2010; Blackburn \& Pennell, 2018). Blackburn further adds that if instructors augments the limit of every student, most students will actually be able to grasp significant ideas adequately. There are two forms of differentiation; external and internal. External differentiation alludes to the streaming of students into various classes as indicated by their levels (Rasheed \& Wahid, 2018). In Malaysian schools, the set system that isolates the students as indication of their English language capability, compares to this thought and surprisingly some time before that, schools have been streaming students into classes by taking into consideration their performance in the year-end summative examination of the previous academic year. This strategy for streaming students has had positive and adverse consequences towards students and parents or guardians. Despite the fact that it makes it simpler for educators to plan and direct exercises, students who have been moved to lower classes may either be persuaded to perform better or be demotivated and focused on the idea that they have been "downgraded" and are answerable to their parents or guardians. Students who have been "advanced" to higher classes might be spurred to perform better or may create presumptuousness which will adversely influence their performance. Notwithstanding, the set framework has now been eliminated and has become obsolete with the rise of DI.

Internal differentiation is where the weightage of the entire methodology lies and where the current study fixates on. DI could be viewed as efficacious and convincing in rebuilding the one-size-fits-all traditional classrooms into ones that obliges the variety in the classroom (Subban, 2006). It gives instructors a compelling stage to amplify learning experience for their diverse students as a differentiated classroom balances learning needs as well as strives to cater to individual learning needs. DI additionally can liberate students from stressing over marking as it offers them the chance to attempt to encounter learning for themselves (Tomlinson, 2013). DI is getting increasingly more notable for its viability and the expectation of enhancing students' results through conscious learning (Yavuz, 2020). According to Tomlinson \& Imbeau (2010), teachers can differentiate classroom instruction in four ways; namely content, process, product and learning environment. The four domains have been extensively explained in many studies.

With the variety in learning styles, speed, abilities and interests in classrooms today, instructors are left with little choice other than adopting differentiated teaching, when teaching effectiveness is of concern. Teachers risk not meeting students' needs if all the students are taught using the same method or strategy 
(Lingo et al., 2011). Despite the fact that DI appears to be a potential goal for grappling with heterogeneous classes, and along these lines augmenting accomplishment, most instructors decide to draw in themselves in the more seasoned methodologies of teaching and keep away from embracing DI in English language educating (Yavuz, 2020). This was also highlighted by Pozas et al. (2020) and Dixon et al. (2014) who referenced that despite the fact that DI has been given its due significance, numerous classrooms are still structured to cater to one-size-fits-all type of teaching. With the myriad studies that have been conducted on DI, this phenomenon is quite explainable.

The genuine capability of DI could be best brought out when educators are relaxed and motivated, and when the right environment for appropriate execution is set up for instructors and students (Joseph, 2013). Challenges should be distinguished and managed quickly in ensuring that learning is fair to all students. All changes come with challenges of its own. However, the true weight of the advantage that a change could bring lies in how the challenges are handled.

Therefore, knowing the factors that influence the implementation of DI would be the first step in understanding the phenomenon and acknowledging the issues present.

\section{Methodology}

The aims of this study were achieved through a qualitative approach. The participants for the interviews were English language teachers from rural and urban secondary schools of Johor Bahru. There are a total of 40 secondary schools in Johor Bahru; of which five are rural schools and the rest urban schools. The information regarding school categories were obtained from the Malaysian Ministry of Education. All five rural schools were selected for the sample whereas random sampling method was employed to choose five urban schools. For this purpose, as Zikmund (2002) recommended, a random number generation tool was used to determine the urban schools to be selected. This is to ensure equal comparison between both categories. Once the schools were determined, purposive sampling method was used, where all English language teachers, optionist or non-optionist, teaching lower secondary were respondents for the questionnaires. The participants for the interview in a few schools were then selected by the assistant principal of the afternoon session. Interviews were conducted till the data reached a saturation point. The sample for semi-structured interview was selected through convenience sampling and the sample size was decided based on the principle of replication in which a number of samples are first selected and investigated with the intention and expectation of identifying replications of certain findings till data reaches a saturation point. Thus, the total number of interview participants is ten and this is justifiable as there are representatives from each school being investigated in this study.

The key items in the interview questions relating to the factors influencing DI employment have been adapted from issues raised by Whipple (2012), who used 
it to investigate DI implementation by teachers in public schools of Boston, Massachusetts, Siam \& Al-Natour (2016), who carried out a study measuring the extent of DI implementation by teachers in Jordan and Aldossari (2018), who conducted studies on the challenges that teachers face in regard to DI implementation in Saudi Arabia. The interview questions were validated by three arbitrators in the field of English language teaching. To maintain confidentiality, teachers of rural schools were labeled as "RT" whereas teachers of urban schools were labeled as "UT". The results of the interview were thematically analysed through NVivo 12 Plus to identify the factors influencing DI implementation in English language instruction.

\section{Results and Discussion}

The thematic analysis conducted on the findings revealed that the factors that need to be considered in the implementation of DI range from school administration to the students. Figure 1 outlines the factors that were revealed.

Figure 1 shows that the codes, or the factors that teachers of rural and urban schools mentioned as influencing the implementation of DI in the teaching of English language. The six main factors are pertaining to Curriculum, Instruction, Knowledge of DI, School, Time and Workload. These were the factors

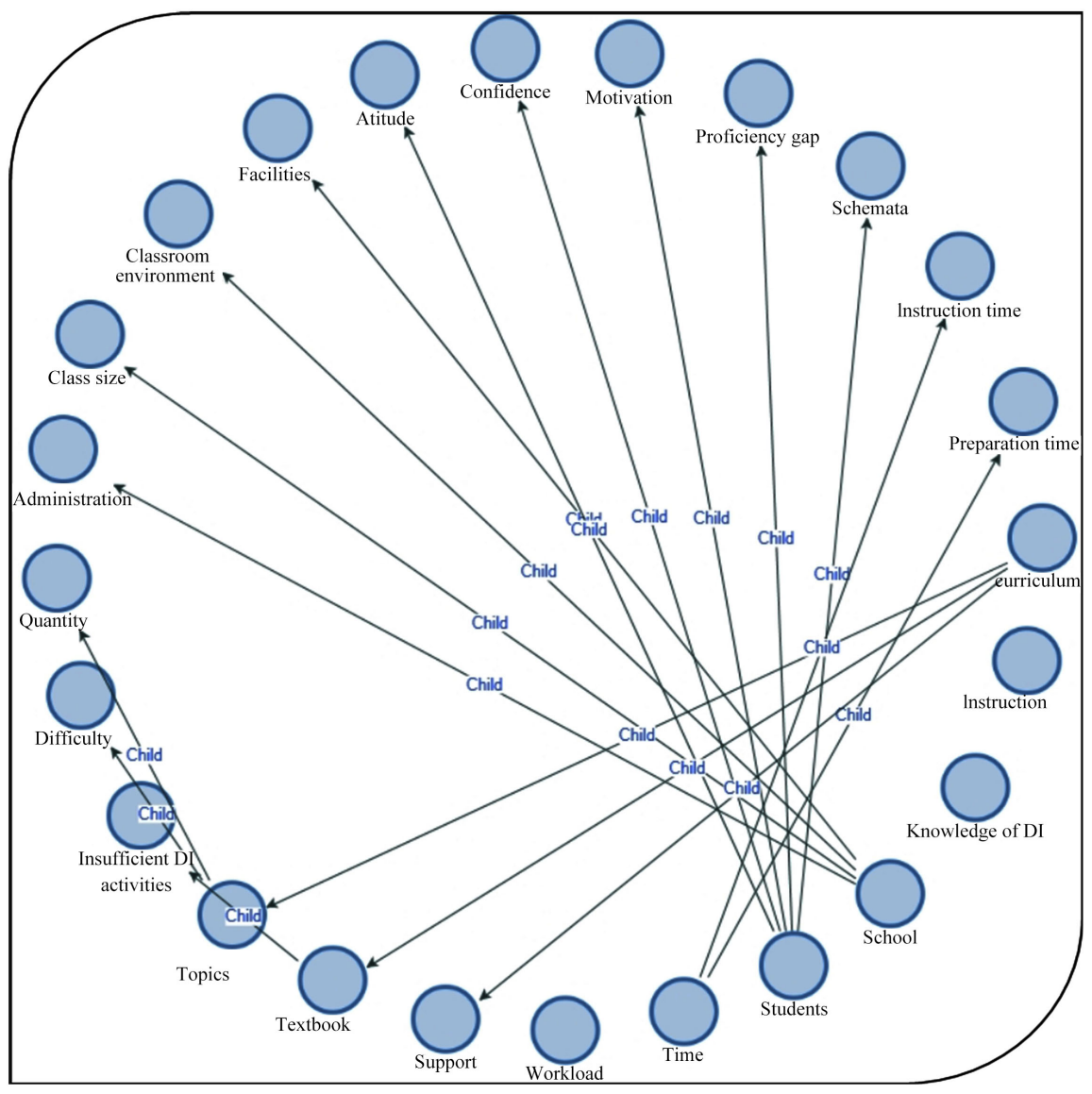

Figure 1. Factors influencing DI implementation. 
mentioned by the teachers during the interview. These factors were further thematically analysed, and 14 themes were identified; namely "Support", "Textbook" and "Topics" under "Curriculum", "Administration", "Class size", "Classroom environment" and "Facilities" under "School", "Attitude", "Confidence", "Motivation", "Proficiency gap", and "Schemata" under "Students", and "Instruction" and "Preparation" under "Time". Following this, 3 other codes were created from thematically analysing two of the abovementioned challenges; namely "Insufficient DI activities" under "Textbook" and "Difficulty" and "Quantity" under "Topics".

Factors related to "teaching" refer to aspects that teachers must consider during class. This includes all stages of the course, teacher's teaching, classroom activities and classroom management. According to the teachers, they are facing the need to communicate in Mandarin, which is also the mother tongue of most students in the classroom. In addition, students also tend to perform classroom tasks in their native language. The use of mother tongue is consistent with similar research conducted by Magableh \& Abdullah (2020), which focuses on the challenges faced by teachers. Yetnayet (2020) also mentioned this finding. He investigated the knowledge, practice and challenges teachers face in implementing DI. In addition, as the research of Heacox (2012) and Suprayogi et al. (2017) reveals, when students are unwilling to cooperate or are not interested in activities, teachers in this research also face challenges in classroom management.

"Knowledge of DI" refers to the problems faced by teachers due to deficiencies or misunderstandings of DI. It turns out that one of the challenges faced by the participants in this study in implementing DI is the lack of DI knowledge. Yetnayet (2020), Moosa \& Shareefa (2019), Turner (2017) and Lunsford (2017) also made similar findings. The aspects related to "school" are related to school facilities, classroom environment, class size and school management. A study conducted by Siam \& Al-Natour (2016), Moosa \& Shareefa (2019) and Turner (2017) also mentioned this factor. The focus of the study is on the challenges teachers face in implementing DI.

Besides that, factors involving "Students" refers to students' attitude, motivation, confidence, proficiency gaps and schemata. Magableh \& Abdullah (2020), Moosa \& Shareefa (2019), Suprayogi et al. (2017) highlighted these factors in their studies investigating the DI-related challenges.

"Time" refers to the factors considered by the teacher. These factors are related to the "teaching time" (the time the teacher is in class) and the "preparation time" (the time the teacher is in the class). Time is a crucial factor, and all the teachers interviewed mentioned time. Many studies (Yetnayet, 2020; Stackhouse, 2018; Siam \& Al-Natour, 2016) focus on the challenges teachers face in implementing DI, and time is a factor highly expressed by the participants. "Workload" refers to the number of tasks completed by teachers in the school. This includes the number of courses they teach, the services they provide to schools and students in addition to teaching, and the administrative positions they hold. The high workload is not only a problem for teachers in Malaysia, but 
also a problem for teachers in Ethiopia (Yetnayet, 2020).

Factors related to "curriculum" refer to the problems faced by teachers in the curriculum set by the Malaysian Ministry of Education, teaching support, textbooks, and topics in textbooks or workbooks. It turns out that teachers believe that the number and difficulty of the topics in the textbook make the implementation of DI more challenging. Previous studies that investigated the challenges faced by teachers in the implementation of DI did not report on curriculum-related challenges. This exclusivity may be due to the new curriculum, work plan, curriculum plan structure and textbooks following the educational reform in 2018. The education reforms that began in 2018 have brought about major changes to the language of Malaysia. This has resulted in teachers having to change their methods of preparing lessons, teaching and evaluating English language.

Generally, it was found that teachers consider aspects related to Curriculum, Instruction, Knowledge of DI, School, Students, Time and Workload in the implementation of DI.

Considering the second research question which seeks to investigate if there is a difference between the factors considered by teachers of rural and urban schools, the following findings were revealed.

From the findings illustrated in Table 1, it could be derived that overall, there are no differences between the factors rural and urban school teachers consider in the implementation of DI. However, it is worth noting that only one out of five rural school teachers mentioned factors related to "Instruction" whereas three out of five urban school teachers mentioned it during the interview. This could be due to the proficiency of the students in urban schools that is relatively higher compared to students in rural schools (Ameirul \& Suyansah, 2017). Therefore, it requires urban school teachers to carry out meticulous planning of stages and follow-up classroom techniques during English lessons.

Table 1. Differences between rural and urban schools.

\begin{tabular}{|c|c|c|c|c|c|c|c|}
\hline \multirow{2}{*}{ PARTICIPANTS } & \multicolumn{7}{|c|}{ FACTORS INFLUENCING DI IMPLEMENTATION } \\
\hline & Curriculum & DI Knowledge & Instruction & School & Time & Students & Workload \\
\hline \multicolumn{8}{|c|}{ Rural school teachers } \\
\hline RT1 & & & & I & & / & / \\
\hline RT2 & / & I & & I & I & I & I \\
\hline RT3 & / & I & & & I & l & \\
\hline RT4 & I & I & I & I & I & I & / \\
\hline RT5 & / & & & & l & I & / \\
\hline \multicolumn{8}{|c|}{ Urban school teachers } \\
\hline UT1 & & & & I & I & I & I \\
\hline UT2 & I & & I & I & & I & I \\
\hline UT3 & I & I & & I & I & I & I \\
\hline UT4 & I & & I & I & I & & I \\
\hline UT5 & I & 1 & I & & I & I & \\
\hline
\end{tabular}




\section{Conclusion and Implications}

Through semi-structured interviews, this study focused DI on oral English classes by studying the factors affecting DI in rural and urban schools in Johor Bahru. It was made known that teachers have to consider many factors in the process of implementing DI. Each of the factors mentioned was accompanied with challenges that teachers face in relation to DI implementation. Further studies could narrow on this aspect as it is crucial to acknowledge the challenges that teachers face and look for possible solutions in order to ensure that DI is implemented accurately and the advantages of DI-based education could be enhanced.

This research has made a significant contribution in the form of valuable feedback needed by decision makers who have structured education reforms and promoted direct investment in the field of English teaching in Malaysia. Obviously, teachers in rural schools lack perfect DI knowledge. Teachers in urban schools indicated that they needed DI training. Remember, it has been 3 years since the implementation of DI. Therefore, it is very important to train teachers and other forms of instruction so that they can master the knowledge and skills needed to implement DI and deal with the challenges they face. The true effectiveness of DI can only be seen after it is actually implemented in the way it should be in theory. It is hopeful that "intensive need-based on-the-job training" could be given by professionals in the field to achieve the abovementioned outcome the soonest possible (Gonne, 2020).

\section{Acknowledgements}

Sincere gratitude goes to all the teachers who were willing to be a part of this study by allocating their time and valuable feedback.

\section{Conflicts of Interest}

The authors declare no conflicts of interest regarding the publication of this paper.

\section{References}

Aldossari, A. T. (2018). The Challenges of Using the Differentiated Instruction Strategy: A Case Study in the General Education Stages in Saudi Arabia. International Education Studies, 11, 74-83. https://files.eric.ed.gov/fulltext/EJ1175296.pdf https://doi.org/10.5539/ies.v11n4p74

Ameirul, A., \& Suyansah, S. (2017). ESL Teaching in Rural Schools: An Investigation of Teachers' Stress and Coping Strategies. International Conference on Language Studies, Kuching, Sarawak, 9-10 August 2017, 506-514.

Aruna, P. (2014). No Emphasis and Poor Teachers the Causes, Say Employers. The Star, 11 December 2014.

http://www.thestar.com.my/News/Nation/2014/12/11/Fresh-graduates-struggling-Noemphasis-and-poor-teachers-the-causes-say-employers/

Blackburn, M. V., \& Pennell, S. M. (2018). Teaching Students to Question Assumptions 
about Gender and Sexuality. Phi Delta Kappan, 100, 27-31.

https://doi.org/10.1177/0031721718803566

Dixon, F., Yssel, N., McConnell, J., \& Hardin, T. (2014). Differentiated Instruction, Professional Development, and Teacher Efficacy. Journal for the Education of the Gifted, 37, 111-127. https://doi.org/10.1177/0162353214529042

Don, Z. M., Abdullah, M. H., Abdullah, A. C., Lee, B. H., Kaur, K., Pillai, J., \& Hooi, M. Y. (2015). English Language Education Reform in Malaysia: The Roadmap 2015-2025. Putrajaya: Ministry of Education.

Gonne, M. A. (2020). The Practices and Challenges of Differentiated Instruction: The Case of Selected Government Upper Primary Schools in Gondar City Administration.

Heacox, D. (2012). Differentiating Instruction in the Regular Classroom. Minneapolis, MN: Free Spirit Publishing. (e-book)

https://www.freespirit.com/files/original/Differentiating-Instruction-Regular-Classroo m-preview-1.pdf

Jacobse, A. E., Meijer, A., Helms-Lorenz, M., \& Maulana, R. (2019). Differentiated Instruction in Secondary Education: A Systematic Review of Research Evidence. Frontiers in Psychology, 10, 2366.

https://www.frontiersin.org/articles/10.3389/fpsyg.2019.02366/full https://doi.org/10.3389/fpsyg.2019.02366

Jalleh, J. (2013). Majority of Teachers Not Proficient in English. The Star, 2 June 2013. http://www.thestar.com.my/News/Nation/2012/09/26/Majority-of-teachers-not-profici ent-in-English/

Joseph, S. (2013). Differentiating Instruction: Experiences of Pre-Service and In-Service Trained Teachers. https://uwispace.sta.uwi.edu/dspace/handle/2139/17611

Lavania, M., \& Nor, F. B. M. (2020). Barriers in Differentiated Instruction: A Systematic Review of the Literature. Journal of Critical Reviews, 7, 293-297. http://www.jcreview.com/fulltext/197-1587743797.pdf

Lingo, A., Barton-Arwood, S., \& Jolivette, K. (2011). Teachers Working Together: Improving Learning Outcomes in the Inclusive Classroom-Practical Strategies and Examples. Teaching Exceptional Children, 43, 6-13. https://doi.org/10.1177/004005991104300301

Lunsford, K. J. (2017). Challenges to Implementing Differentiated Instruction in Middle School Classrooms with Mixed Skill Levels. PhD Thesis, Minneapolis, MN: Walden University. https://scholarworks.waldenu.edu/dissertations

Magableh, I. S. I., \& Abdullah, A. (2020). On the Effectiveness of Differentiated Instruction in the Enhancement of Jordanian Students' Overall Achievement. International Journal of Instruction, 13, 533-548. http://www.e-iji.net/dosyalar/iji 20202 37.pdf https://doi.org/10.29333/iji.2020.13237a

Mohamed, A. R., Tumin, M., \& Omar, H. (2008). Success Structure for Accelerated Acquisition of English by Young ESL Learners. Educational Research and Review, 3, 169-181. https://eric.ed.gov/?id=EJ893987

Moosa, V., \& Shareefa, M. (2019). The Impact of Teachers' Experience and Qualification on Efficacy, Knowledge and Implementation of Differentiated Instruction. International Journal of Instruction, 12, 587-604. https://doi.org/10.29333/iji.2019.12237a

Nor, F. M, Aziz, M. A. \& Jusoff, K. (2011). Should English for Teaching Mathematics and Science (ETeMS) in Malaysia Be Abolished? World Applied Sciences Journal, 12, 36-40.

https://www.semanticscholar.org/paper/Should-English-for-Teaching-Mathematics-an d-Science-Nor-Aziz/eddda9ac179d6ff1a0bb711cb2b801bc9f7c04a9 
Norfaizah, M., \& Marzilah, A. (2010). ETeMS: The Implications on Learners. Research in English Language Teaching, 1, 1-9. https://core.ac.uk/download/pdf/11794188.pdf

Pozas, M., Letzel, V., \& Schneider, C. (2020). Teachers and Differentiated Instruction: Exploring Differentiation Practices to Address Student Diversity. Journal of Research in Special Educational Needs, 20, 217-230.

https://nasenjournals.onlinelibrary.wiley.com/doi/pdf/10.1111/1471-3802.12481

https://doi.org/10.1111/1471-3802.12481

Rasheed, F., \& Wahid, A. (2018). The Theory of Differentiated Instruction and Its Applicability: An E-Learning Perspective. VSRD International Journal of Technical \& Non-Technical Research, 9, 193-201.

https://www.researchgate.net/publication/324843878

Rashid, R. A. (2016). Topic Continuation Strategies Employed by Teachers in Managing Supportive Conversations on Facebook Timeline. Discourse Studies, 18, 188-203. https://journals.sagepub.com/doi/abs/10.1177/1461445615623906 https://doi.org/10.1177/1461445615623906

Robinson, L. (2013). A study of Teachers' Attitudes, Thoughts, and Perceptions about Successful Implementation of Differentiated Instruction. Available from ProQuest Dissertations \& Theses Global. https://vpn.utm.my/docview/1468935543?accountid=41678

Schleicher, A. (2016). Teaching Excellence through Professional Learning and Policy Reform: Lessons from Around the World. Paris: International Summit on the Teaching Profession; OECD Publishing. https://doi.org/10.1787/9789264252059-en

Selamat, A., Esa, A., \& Saad, S. S. (2011). Teaching and Learning Mathematics and Science in English in Primary Schools in the State of Johor, Malaysia. Journal of Education.

Selvaraj, B (2010). English Language Teaching (ELT) Curriculum Reforms in Malaysia. Voice of Academia, 5, 51-60.

Siam, K., \& Al-Natour, M. (2016). Teachers' Differentiated Instruction Practices and Implementation Challenges for Learning Disabilities in Jordan. International Education Studies, 9, 167-181. https://files.eric.ed.gov/fulltext/EJ1121601.pdf https://doi.org/10.5539/ies.v9n12p167

Stackhouse, W. (2018). Teaching Julius Caesar with Differentiated Instruction: A Curriculum Unit Approach. https://digitalcommons.hamline.edu/hse cp/150

Subban, P. (2006). Differentiated Instruction: A Research Basis. International Education Journal, 7, 935-947. https://files.eric.ed.gov/fulltext/EJ854351.pdf

Suprayogi, M. N., Valcke, M., \& Godwin, R. (2017). Teachers and Their Implementation of Differentiated Instruction in the Classroom. Teaching and Teachers Education, 67, 291-301. https://doi.org/10.1016/j.tate.2017.06.020

Tahiri, J. S., Bennani, S., \& Idrissi, M. K. (2017). diffMOOC: Differentiated Learning Paths Through the Use of Differentiated Instruction within MOOC. International Journal of Emerging Technologies in Learning, 12, 197-218. https://doi.org/10.3991/ijet.v12i03.6527

Tomlinson, C. A., \& Imbeau, M. B. (2010). Leading and Managing a Differentiated Classroom. Alexandria, VA: ASCD.

Tomlinson, C. A., \& Moon, T. R. (2013). Assessment and Student Success in a Differentiated Classroom. ASCD.

Turner, W. D., Solis, O. J., \& Kincade, D. H. (2017). Differentiating Instruction for Large Classes in Higher Education. International Journal of Teaching and Learning in Higher 
Education, 29, 490-500. https://files.eric.ed.gov/fulltext/EJ1151047.pdf

Valiandes, S. (2015). Evaluating the Impact of Differentiated Instruction on Literacy and Reading in Mixed Ability Classrooms: Quality and Equity Dimensions of Education Effectiveness. Studies in Educational Evaluation, 45, 17-26. https://doi.org/10.1016/j.stueduc.2015.02.005

Van Casteren, W., Bendig-Jacobs, J., Wartenbergh-Cras, F., Van Essen, M., \& Kurver, B. (2017). Differentiëren en differentiatievaardigheden in het primair onderwijs (Report). Nijmegen: ResearchNed.

Whipple, K. A. (2012). Differentiated Instruction: A Survey Study of Teacher Understanding and Implementation in a Southeast Massachusetts School District. Doctoral Dissertation, Boston, MA: Northeastern University.

https://repository.library.northeastern.edu/files/neu:1180/fulltext.pdf

Yavuz, A. C. (2020). The Effects of Differentiated Instruction on Turkish Students' L2 Achievement, and Student and Teacher Perceptions. Eurasian Journal of Applied Linguistics, 6, 313-335. https://doi.org/10.32601/ejal.776002

Yetnayet, W. (2020). Knowledge, Practices and Challenges of Implementing Differentiated Instruction among Primary School Teachers in Bahir Dar City. Doctoral Dissertation, Bahir Dar City

Zikmund, W. G. (2002). Business Research Methods (8th ed.). Dryden: Thomson Learning.

https://www.academia.edu/33978482/Business Research Method Zikmund 8th editi on pdf 